\title{
THE PLACE AND ROLE OF THE WELDING SPECIALIST IN THE DESIGN AND EXECUTION OF WELDED STEEL CONSTRUCTIONS
}

\author{
Radu Băncilă
EdwardPetzek $^{1}$ \\ Radu Băncilă
EdwardPetzek $^{2}$ \\ Anamaria Feier ${ }^{3}$ \\ Anamaria Feier
Dorin $\mathrm{Radu}^{4}$
}

DOI: 10.14415/konferencijaGFS2019.001
Summary: The emergence of new efficient materials, innovative welding processes, the
high demands on the quality of the welded joints, while ensuring their safety in
operation, outstanding aesthetic forms, the complexity of the new European welding
standards, the pressure of the short execution times, lead to the need to emphasize the
multidisciplinary character of the welding field, and a re-evaluation of the education in
this direction. The paper presents some general aspects regarding the present problems
in this direction, including the choice of the steel quality in welded steel structures.

Keywords:Historical welded structures, present trends in welded steel Constructions

\section{INTRODUCTION}

Welding is essential in many aspects of our everyday lives: infrastructure, economy, military, aerospace and arts. Welders build the world we live in. From cars to high rise office buildings, bridges, airplanes, none of it would be possible without welding. Practically riveted and bolted connections are used today, only in special cases. Seventy percent of all manufactured products are made with the skills of welders. Welders are not simple laborers, but technicians and scientists who are pushing the world into the future. Different studies found that the connection between welding and economics will continue to keep educated welders in high demand. Welding can be considered as an architectural art, creating the world in which we live, work and shop. Welding is a part of everything around us; without welding we wouldn't be able to do the things we do.

The emergence of new efficient materials, innovative welding processes, the high demands on the quality of the welded joints, while ensuring their safety in operation, the

\footnotetext{
${ }^{1}$ Radu Băncilă , Professor Emeritus Dr. Ing.Universitatea Politehnica Timisoara/Romania, Str. Tr. Lalescu 2a, 300224 Timisoara, E- mail: radu.bancila45@gmail.com

${ }^{2}$ Edward Petzek, ProfessorDr. Ing.Universitatea Politehnica Timisoara/Romania, Str. Tr. Lalescu 2a, 300224 Timisoara,Email: epetzek@ssf.ro

3 Anamaria Feier, Lector dr. Ing. Universitatea Politehnica Timisoara/Romania and Romanian Welding Society,Email: anamaria_butisca@yahoo.com.au ${ }^{4}$ Dorin Radu, Faculty of Civil Engineering, Transilvania University of Braşov, 500152 Turnului street no.5, Brașov, Romania, Email: dorin.radu@indomo.ro
} 
outstanding aesthetic forms, the complexity of the new European welding standards, the pressure of the short execution times, lead to the need to emphasize the multidisciplinary character of the welding field, and of re-evaluation the education in this direction. The collaboration between the architect, the welding steel designer and the welding specialist is now essential. At the same time, in a global economy, a harmonization of the welding education becomes necessary. The aim of this paper is to establish general recommenddations in the field of design (including the choice of material) and execution of welded steel constructions as well as of the high-level education in welding.

\section{THE BEGINNINGS}

The industrial revolution, started in the XVIII century, led to the intensive increase of metal production and the improvement of the elaboration methods.

The cast iron constructions, conceived as arch structurea, allowed telatively large spans, one of the first cast iron structures is the bridge in Coalbrookdale (1778), an arch with the span of $\mathrm{L}=31 \mathrm{~m}$, still in use as pedestrian bridge. The cast iron structures, especially bridges had not given the expected results, yet as the use of this material needs complicated works and high costs. Additionally, the cast iron was brittle, having low tensile strength, producing many accidents, which made it, in time, to be forbidden in bridge construction.

The appearance of the wrought steel at the end of the XVIII century (1784) and then of mild steels (Bessemer in 1856 and Thomas in 1880), leads to the construction of steel structures and bridges having more and more large spans and even records, such as the double railway bridges, Firth of Forth (1890) in Scotland with the two spans of $521 \mathrm{~m}$ and Quebec (1917), with the central span of $548 \mathrm{~m}$. All the connection was riveted. The appearance and development of welding, as well as the economic advantages of welded connections, through the reduction of the fabrication costs and of the metallic material, imposed this new assembling technology for structures.In the beginning the same mild steel was used and the same joining types and constructive details as for riveted metallic bridges, without noting the necessity to obtain steels with special weldability characteristics and the use of specific constructive solutions.But the first practical results were discouraging. The series of accidents begun in 1938 when a span of the Rüdersdorf viaduct, one of the 50 welded plate girder bridges, built in the period 1931-1937 in Germany, collapsed. The cause of the accident was a crack in one of the lower flanges of the main girder.These events led to the suspension, in Germany, of welded bridge execution. Researches made in that period, continued after the II World War, led to the following conclusions:

- fractures produced since material becomes brittle in the heat affected zone;

- welding is not contra-indicated for bridges, but it is necessary to use a steel having optimum welding conditions;

- welded constructions must be rigorous executed and controlled;

- it is necessary to adopt suitable constructive details, to avoid stress concentrations;

- necessity of some new quality weldable steels, like killed steels, fine grained steels, limiting the carbon content to maximum $0.2 \%$ and manganese to $0.75-1.70 \%$, in addition with vanadium, nickel and aluminum. 
Contemporary achievements in civil engineering 23-24. April 2019. Subotica, SERBIA

- Welded constructions also bring a significant reduction in workmanship, ensuring a direct transmission of efforts

The improved welding technology, as well as the new weldable steel grades, impelled the appearance of new steel structures and bridges, with specific constructive solutions for welded joints.

In Romania the first important applications in the fieldwelding occurred after the First World War.At first, rail and tram rails,but later, the new joining technology has rapidly expanded to several constructions inrailway industry, oil industry, etc. One important. Stepin the introduction of welding technique in our country was the "Circle for the encouragement of welding"founded in 1937, at the initiative of the Rector of the Polytechnic Schoolfrom Timisoara, C.C. Teodorescu and Prof. CorneliuMikloşi.

In the interwar period a series of remarkable welded constructions were executed, such as:

- The Palace of the Phones in Bucharest (1937) - Figure 1;

- CFR Palace with a height of H = 52.5 m, builtin the period 1929-1934 - Figure 2.

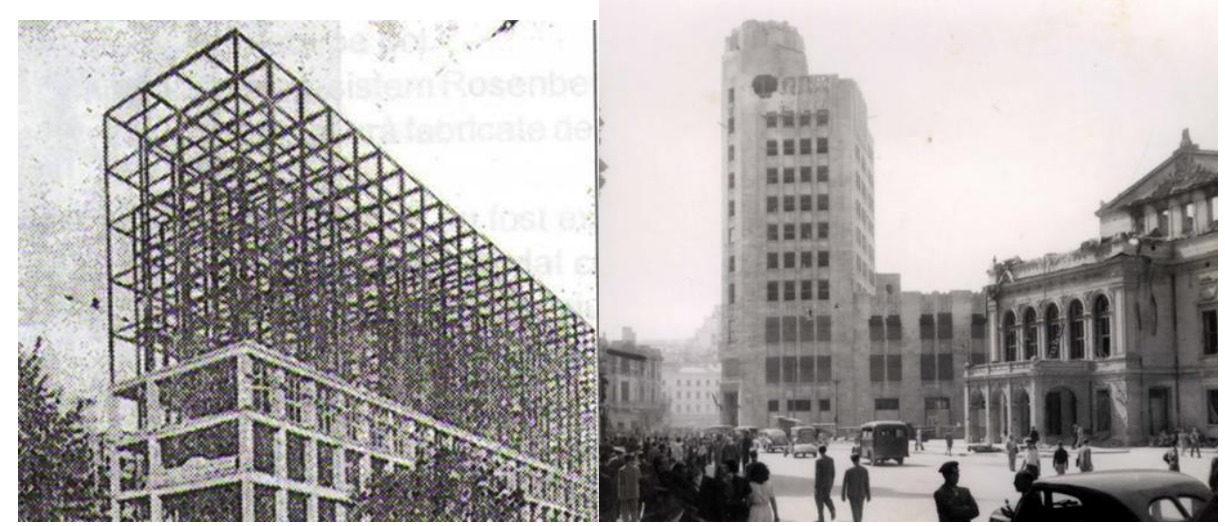

Fig. 1 Railway administration building Fig. 2 Telephone Center $H=52,5 \mathrm{~m}$, built (1937) between 1929 - 1934

In our country, the first welded steel bridge wasbuilt at Resita in 1937, over the river Bârzava, with a span of $31.42 \mathrm{~m}$ and a central height $\mathrm{H}=4.0 \mathrm{~m}$ (Figure 5). It was one of the first bridgesfully welded from Europe. The bridge is also in present in an good technical condition. 


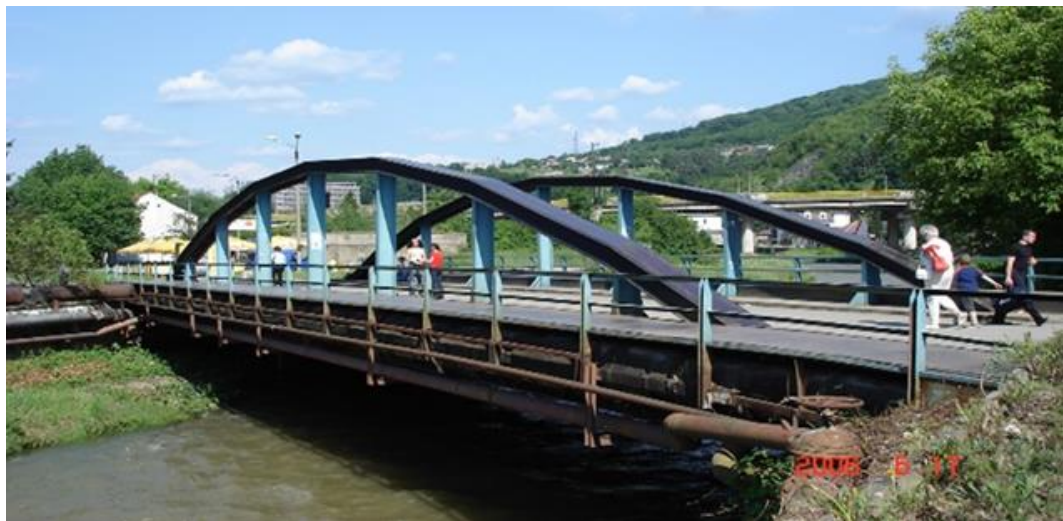

Fig. 3 The first welded steel bridge built in Reșița in 1937, over the Bârzava River, with a span of $31.42 \mathrm{~m}$

After 1950, welding as a means of joining insteel constructions begin to become generalized. The experienceaccumulated in this field, but especially the exceptionally human capitalexisting in Timisoara, as well as a seriesof personal initiatives, led to the establishment in 1970 of the Institute for Welding and Testing of Materials. In the field of bridges, the first completely welded bridge with a large span, was erected in 1970 over the Danube (Fig. 4).
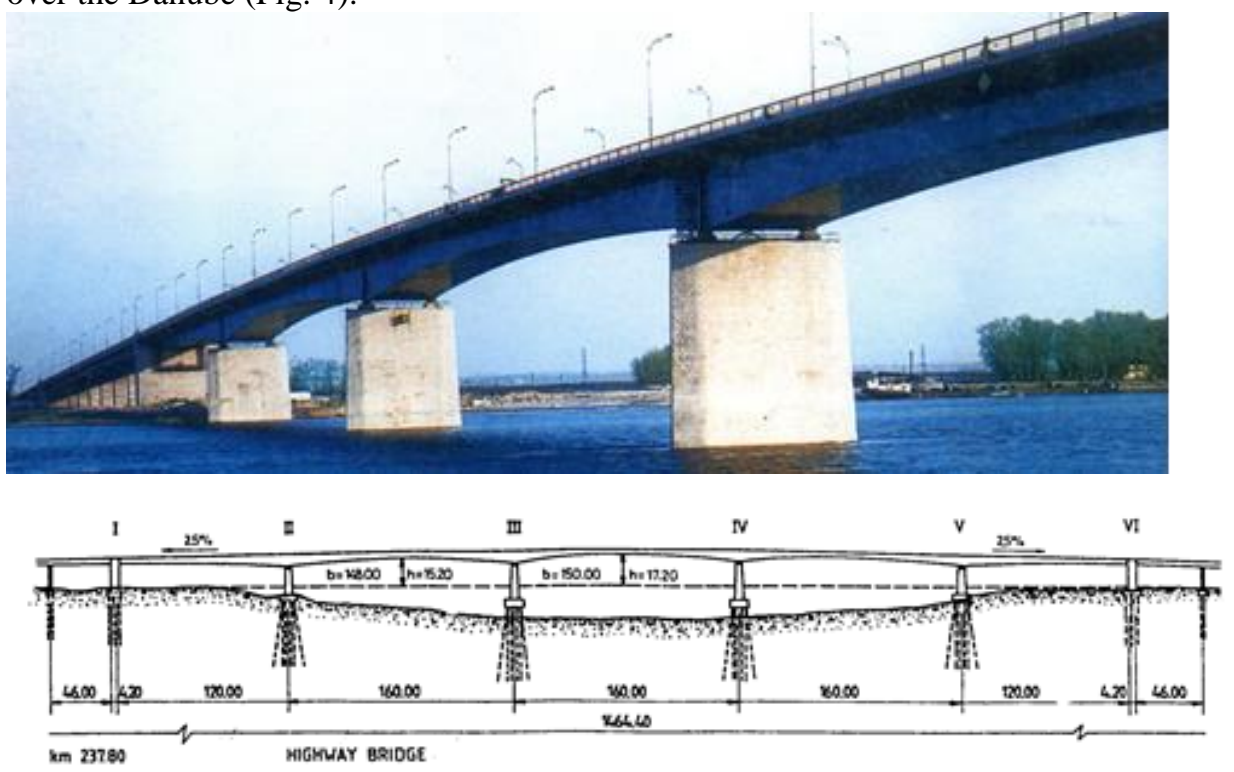

Fig. 4 The highway Danube bridge in Giurgeni - VadulOii (1970)

A big impulse in welded steel constructions was the Complex of the New Danubian Bridges (over 50000 Tonnes of welded Steel Bridges in the period of 1976 - 1988). 
Contemporary achievements in civil engineering 23-24. April 2019. Subotica, SERBIA

\section{PRESENT TRENDS IN WELDED STEEL CONSTRUCTIONS}

In the last two decades some an important progress was made in the field of welded steel constructions; in the following the most important aspects are analyzed.

1. New Steels $\rightarrow$ New Products $\rightarrow$ New Solutions (Fig. 5);
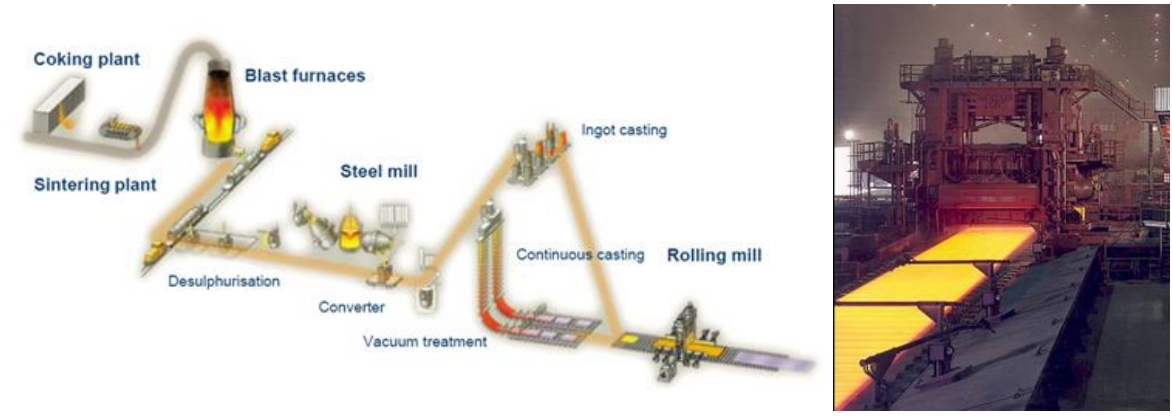

\section{AR $\quad \mathrm{TM} \quad \mathrm{Q}+\mathrm{T} \quad \mathrm{N}$}

Fig. 5 New products in steel fabrication

2. Introduction of the thick plates in industrial and bridge constructions (Fig. 6)

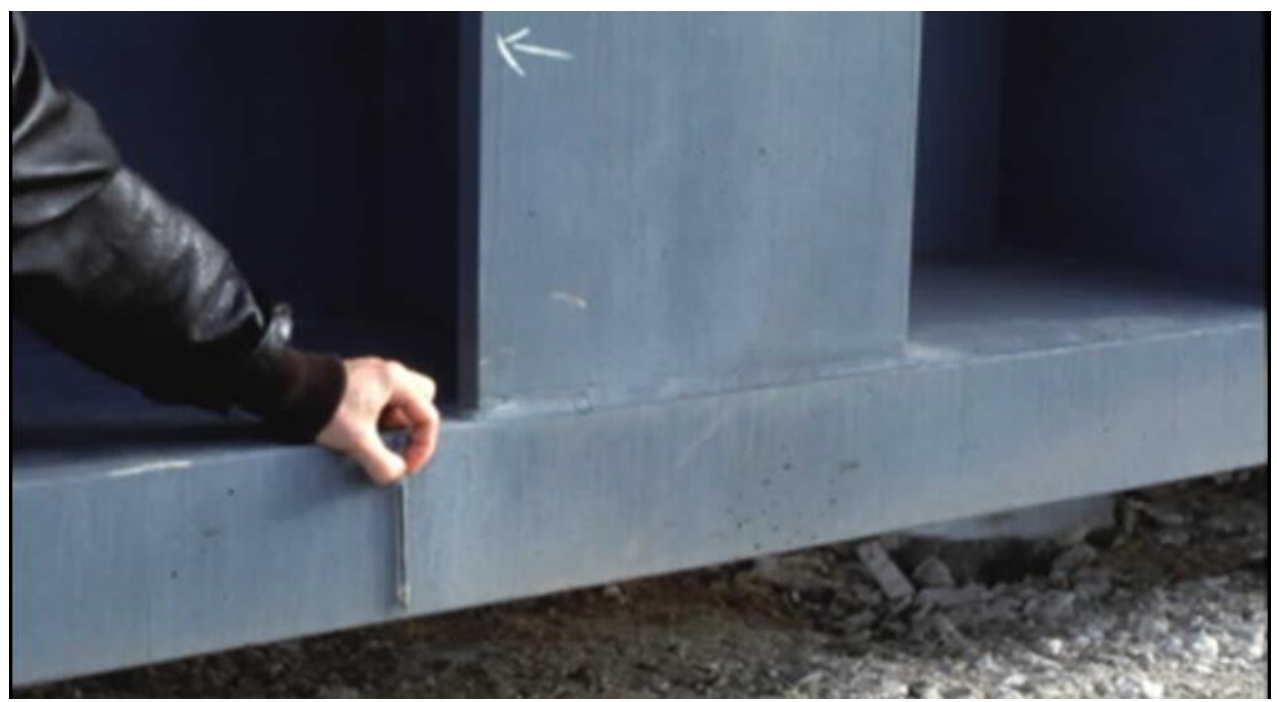

Fig: 6 Thick flange in composite bridges

3. Application of high strength steel grades; in Eurocode - Section EN 1993-1-12 Steels with high yielding force (S690) are presented. A comparative analyze of two modern steels is presented in Fig 7. 
Савремена достигнућа у грађевинарству 23-24. април 2019. Суботица, СРБИЈА

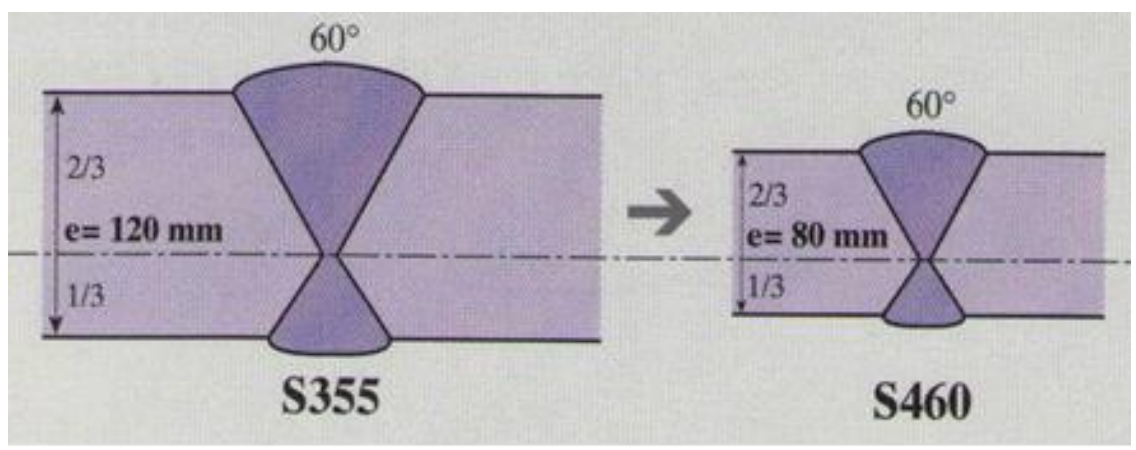

Fig. 7 Comparative analyze of a butt weld.

Using a steel grade $\mathrm{S} 460 \mathrm{M}$, preheating can be avoided.

4. The use of fatigue resistant details (Fig.8). In structures (ex. Bridges) where fatigue is decisive, the use of adequate details according to Eurocode 3 is important. It can improve the behavior in time of the structure. In bridges the recommendation is to use a $\Delta \sigma c 71$ constructive detail.
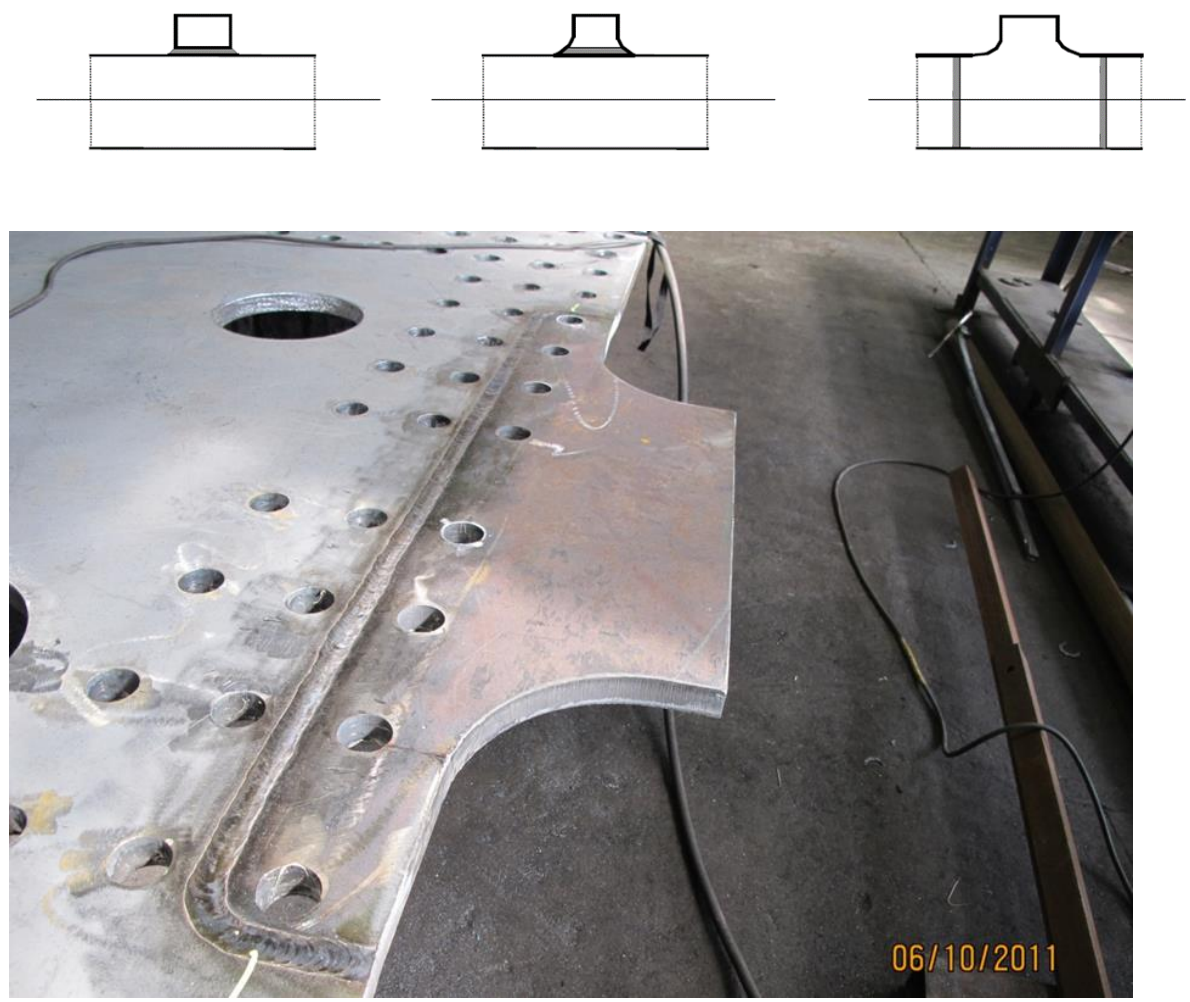

Fig. 8 Fatigue resistant details in bridge construction 
Contemporary achievements in civil engineering 23-24. April 2019. Subotica, SERBIA

5. Computer Aided Design of welded constructions: CAD/CAM/BIM (Fig. 9)

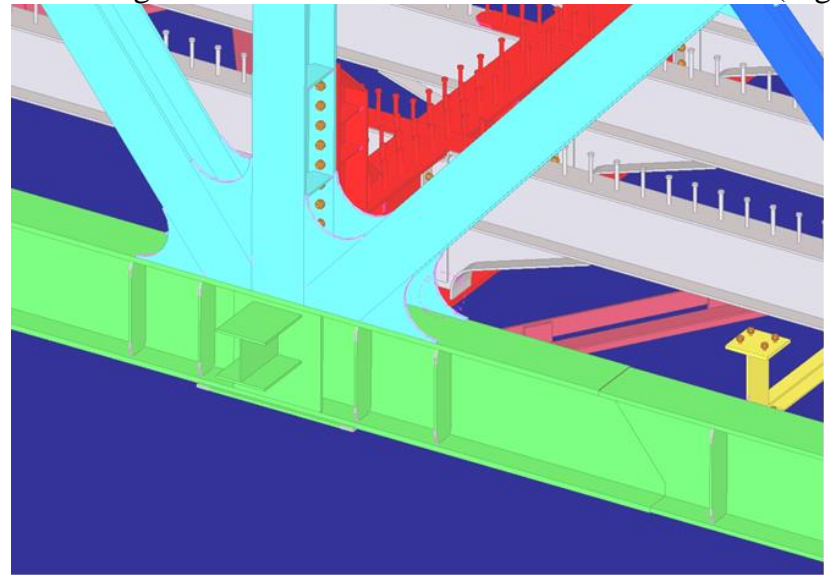

Fig. 9 Truss girder - CAD analysis

6. Choice of material. According to Eurocode the choice of the steel grade had to follow a special methodology (Fig. 10)

\section{Choice of Material (Eurocode Annex 10)}

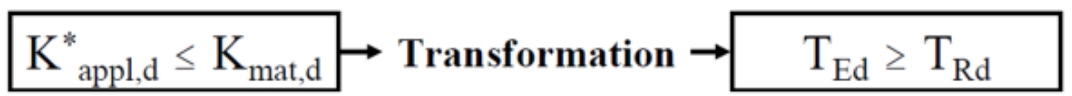

The design value of lowest member temperature $T_{E d}$ with the transition temperature $\mathrm{T}_{\mathrm{Rd}}$

Determination of maximum permissible values of element thickness

$$
\left(\mathrm{S}_{\mathrm{d}} \leq \mathrm{R}_{\mathrm{d}}\right)
$$

$\mathrm{T}_{\mathrm{Ed}}$ represents the minimum design temperature for which the effective stresses in the structure are determined $-\sigma_{\text {appl.d }}$
$T_{R d}$ is the temperature at which a safe level of fracture toughness can be relied upon under the conditions being evaluated

Fig. 10 Choice of material in welded steel constructions

7. Gradually replacement of the classical S235 with S355 or a higher steel grade (Fig.11).

European Standard Steel S355 EN 10025:200

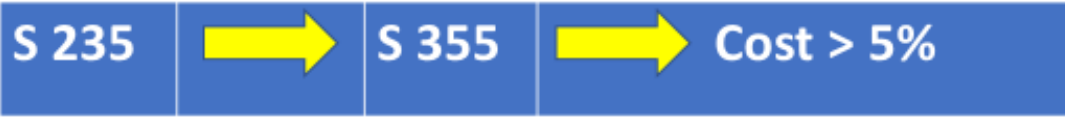

Fig. 11 Current use of S 355 
Савремена достигнућа у грађевинарству 23-24. април 2019. Суботица, СРБИЈА

8. Recommendation for using weathering steels (like S355J0 W - EN 10025-5)

9. Outstanding esthetic forms with higharchitectural impact

10. Choice from the designing stage of the correct execution category, according to EN 1090.

11. Education in welding IWE (International welding Engineer) and IWSD (International Welding Designer)

\section{CONCLUSIONS}

In the present context of the important European Infrastructure Projects the Eurocodes Standards, the necessity of safe and sustainable steel constructions (Fig. 12), the role of the Welding Specialist is decisive. A special attention must be paid to the education in the welding field.

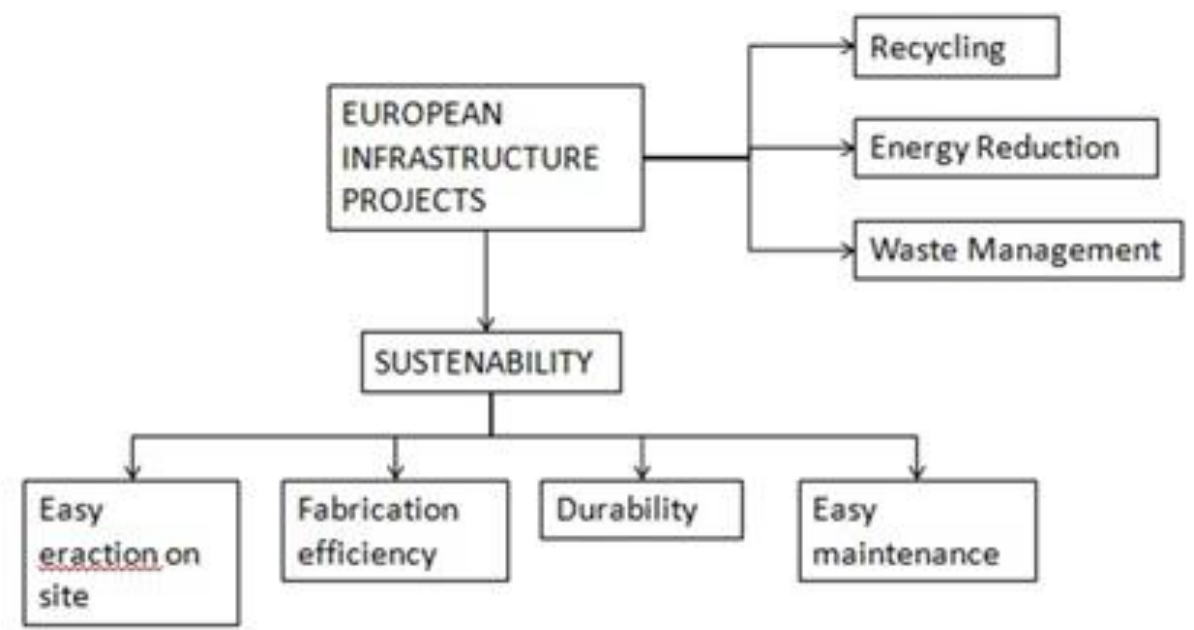

Fig. 12 Sustainability of steel welded structures

Observation: This paper represents a short form of the presentation made during the Round Tablediscussion" Developments in welded steel constructions" held in Timisoara on 6.09.2018, organized by the Romanian Alliance of Technical Universities (ARUT),Politehnica University Timisoara (UPT), and the Romanian Welding Society ASR).A final Statement regarding the importance and necessity of the education in the welding field, was adopted.

\section{REFERENCES}

[1] Eurocodes - Standards 